\title{
Mentioning a Process for Organizational Talent Skill Development
}

\author{
Bandyopadhyay $\mathrm{N}^{*}$ \\ Consulting Engineer, India
}

Submitted: November 28, 2017; Published: December 13, 2017

*Corresponding author: Bandyopadhyay N, Consulting Engineer, Kolkata, India, Tel: 91-33-2452-6436, Email: nbandyopadhyay@hotmail.com

\section{Introduction}

Mentoring is a process, necessary to share experience and knowledge of experienced persons with less experienced persons to help develop their skills to improve performance and help in organizational succession plans. In the following Example, the provisions of mentoring as outlines in the subsequent paragraphs have been adequately explained.

Example: At a top management meeting, the project manager was asked why the client is complaining about lack of planned progress in site work of his project. The project manager asked for some time to know from his site engineer, the reasons. The site engineer informed him that contractor's field workers are deliberately going slowly because they do not get scheduled breaks for tea and snacks. The pm advised him to call the contractor and ask him to allow recess to the workers and as a gesture of goodwill provide them free tea. The labor productivity improved drastically and the project progress exceeded the planned schedule, resulting in early completion. In the end the contractor was paid token bonus for early completion. Everybody was happy.

Mentoring- How it works - Mentoring works through regular on job training (OJT) and guidance in day to day work in an organisation. Periodic in house training by senior persons within the organisation and by external professional training conductors, having long experience in the same business, is essential parts of mentoring. How mentoring is beneficial- It imparts the knowledge about business objectives, growth plans. KPIs, multiple department functions and commitment to social obligations of the organisation at all levels. Consequently the organisation gets a homogenous human resource having identical knowledge about the organisation. This also helps in inter department mobility for improved efficiency within the organisation

\section{Mentoring Styles}

There can be several types of mentoring.

\section{Casual mentoring}

There is no fixed agenda. It is usually carried out during in house progress review meeting, informal discussions on various problems and constraints faced by a department etc. For example, Purchase department facing problems in timely supply of materials of certain specifications so they advise requisition department about the specifications of equivalent material which are available to meet the timing of the consuming department thus avoiding delay.

\section{Informal mentoring}

Usually between limited numbers of participants directly engaged on a specific work where opinions of various parties are essential. For example Planning department makes a network program for project implementation and circulates it to various other concerned departments like design, purchase, project, field construction etc. Based on inputs from these departments the implementation program can be given a practical shape. In other words, informal mentoring helps in effective team performance.

\section{Formal mentoring}

Normally before starting a new venture, senior and experienced persons to brief less senior or inexperienced staff about the problems, challenges and constraints likely to be faced and how to handle them.

\section{Facilitated mentoring}

When in house knowledge and resources are not sufficient to face stiff external competition, the services of highly experienced mentors having wide experience in the subject, will prove to be beneficial. Answers to all these can be found in the Example above. 
(C) This work is licensed under Creative (CC) Commons Attribution 4.0 Licens DOI: 10.19080/JOJMS.2017.03.555614

- Quality Editorial service

- Swift Peer Review

- Reprints availability

- E-prints Service

- Manuscript Podcast for convenient understanding

- Global attainment for your research

- Manuscript accessibility in different formats

( Pdf, E-pub, Full Text, Audio)

- Unceasing customer service

Track the below URL for one-step submission https://juniperpublishers.com/online-submission.php 